\title{
Family-centered care: a scoping review
}

\author{
Andreja Krajnc* \\ Visoka Zdravstvena Šola v Celju, Mariborska cesta 7, 3000 Celje, Slovenia \\ akrajnc9@gmail.com \\ Mateja Berčan \\ Alma Mater Europaea - European centre Maribor, Slovenska ulica 17, 2000 Maribor, \\ Slovenia \\ mateja.bercan@siol.net
}

\begin{abstract}
:
Research Question (RQ): How is family-centered care perceived in scientific literature?

Purpose: To provide a scoping review of the literature about family-centred care.

Method: In databases we searched for the articles using the following searching terms: 'familycentered care,' 'family centeredness,' 'family nursing,' and 'partnering with families.' We gradually excluded the articles that did not meet our conditions. The articles that met our conditions were thematically analysed.

Results: We identified five core characteristics of family-centered care: the importance of communication, involvement of patients and family members, support to family members, organisational aspects, and the importance of nurses' attitudes. We stressed that family-centered care proposes a systematic solution which strives to optimize the level of satisfaction of all included parties, because it perceives healthcare process as an intersubjective reality in which all of the involved parties mutually depend on each other.

Organization: The results of this study might be applied and taken into account in designing a program of healthcare.

Society: The results of this study propose a systematic solution for delivering health care that would improve wellbeing of all included parties.

Originality: The article offers a thematical analysis of the literature and at the same time synthetizes the main characteristic of family-centered care.

Limitations / further research: Only articles published in English language were included. We did not differentiate between different types of healthcare environment.
\end{abstract}

Keywords: family-centered care, family centeredness, partnering with families, family nursing, healthcare, scoping review, communication, systematic solutions

\section{Introduction}

Families are important units of our society. Members of the same family are closely connected and therefore mutually depend on each other. Family is an important concept in the process of health care as well. Individual patients most often belong to one or more family units, and it is, therefore, crucial that this fact is taken into account in organizing and designing healthcare processes. "Family-centered care" is an expression which is used in health care sciences to denote the type of health care which does not concentrate only on patient and patient's individual needs, but at the same time includes patient's family, because 
it treats patient and his family as one recipient of health care services. The practice of familycentered care is thus juxtaposed to patient-centered care which concentrates only on an individual patient and does not systematically involve patient's family in the health care process.

In order to conduct a research concerning family-centered care, one has to be familiar with the findings of other scientists about this topic and thus ought to place oneself into the broader context of the state of research. The past few decades have seen a significant number of studies dedicated to the concept of family-centered care. The concept has developed to such an extent, that there is a need to delineate its basic characteristics as they are present in contemporary researches and theories. Thus, the aim of the present article is to provide a scoping review of the articles that were written and published on the topic of family-centered care in the last eight years and to identify the basic features of the concept of family-centered care. Our research question is, therefore, how family-centered care is perceived in contemporary scientific literature. We will conduct a thematical analysis of methodically selected articles and try to extrapolate the basic characteristics of family-centered care that the contemporary researchers suggest.

\section{Theoretical framework}

The concept of family-centered care is relatively recent. It has its origins in pediatric care which underwent the process of modification after World War II. This modification took place due to the growing awareness that for optimizing child care, parents should be part of the healthcare process and that children should not be left alone in the hospitals. In this regard, the researches of James Robertson and John Bowlby were pivotal (Bowlby 1944a; Bowlby 1944b; Robertson \& Bowlby 1952; Robertson 1970). The importance of familycentered care was gradually acknowledged in all fields of healthcare deliverance. Due to their vicinity and continuous engagement with the patients, nurses were the first to change their working habits as they had to invite and successfully include family members in the process of healthcare (Joolley \& Shields, 2009, p. 167).

Different authors tried to define what Family-centered care is (Davidson et al., 2017, p. 105; Deek et al., 2015, p. 970; Hsu et al., 2019, p. 1; Johnson, 2000; Joolley \& Shields, 2009; Kokorelias, Gignac, Naglie, \& Cameron, 2019, p. 5; Mackie, Michell, \& Marshall, 2019, p. 1; Mitchell, Chaboyer, Burmeister, \& Foster, 2009, p. 543; Park, Giap, Lee, Jeong, \& Go, 2018, p. 69). According to the Institute for Family-centered Care, family-centered care is "an approach to the planning, delivery, and evaluation of healthcare that is governed by mutually beneficial partnerships between healthcare providers, patients, and families" (Kovacs, Bellin, \& Fauri, 2006, p. 14). The same institute further specifies the principles of family-centered care. The concept of family-centered care is closely linked to, or almost identical with the concept of family-focused care which is also mentioned by some scholars, and was as such at first introduced in pediatric care (Deek et al., 2015, p. 970). Family-centered care formalizes each patient and the patient's family as a unit of care (Mitchell, Chaboyer, Burmeister, \& 
Foster, 2009, p. 543) and embraces them as the care-clients (Kokorelias, Gignac, Naglie, \& Cameron, 2019, p. 2). It is respectful and responsive not only to patients' needs and values, but also to the needs and values of their family members (Davidson et al., 2017, p. 105).

Park, Giap, Lee, Jeong, \& Go (2018, pp. 69) identified most common aspects of familycentered care. With regard to patients, family-centered care aims at improving their knowledge about their health, increasing skills to manage self-care behaviors, enhancing satisfaction, increasing quality of life, and reducing the length of their hospital stays; regarding family members, family-centered care tries to reduce the intensity of stress; regarding health care providers, family-centered care interventions could improve job satisfaction and confidence, quality of care, and reduce stress and burnout.

The distinguishing characteristic of family-centered care which differentiates it from other models of health care is that family centered care considers the family of a patient as integral to the process of health care (Mitchell, Chaboyer, Burmeister, \& Foster, 2009, p. 534). The family of a patient is not regarded as an obstacle external to the process of health care, but, on the contrary, as a resource which should be appropriately integrated into the health care processes (Whiston, Barry, O'Keane, \& Darker, 2018, p. 9). The advantage of such an approach is twofold. On the one hand, family members participate in health care of a patient and thus relieve health care providers of some of their work and at the same time improve the quality of health care (Mackie, Michell, \& Marshall, 2019, p. 1). On the other hand family members feel fulfilled and satisfied, because they are involved in the health care process and know what is happening with their beloved one (Park, Giap, Lee, Jeong, \& Go, 2018, p. 69). Despite positive impact that family members can have on the process of health care, some researchers point to possible shortcomings of family-centered care. One of the issues is that family-centered care can additionally complicate the work of health care providers. The research conveyed by Luttik et al. (2016, p. 3) showed, that some nurses regarded patients' families as a burden which caused them additional stress. The presence of such critiques of family-centered care calls for a systematic, organizational model of family-centered care, which takes into account all included parties, i.e., patients, their family members, and health care providers (Foster et al., 2016, pp. 21-22).

From the abovementioned suggestions of different scholars, we can define family-centered care as a model of care that takes into account the system of relationships between the patient, family members, and health care providers. The underlying presupposition for such treatment is a relational approach which understands a human being primarily as an intersubjective reality that can be fully comprehended only from its intersubjective context. Patients and their family members are thus not only passive recipients of health care process, but are acknowledged as active subjects who are as such crucial in planning and delivering of health care. 


\section{Method}

We conducted a thematic analysis of scientific literature dedicated to the concept of familycentered care and its characteristics. We searched for the literature in the following databases: CINAHL, PubMed, Medline, ProQuest, and Google Scholar. The search terms 'familycentered care,' 'family centeredness,' 'family nursing,' and 'partnering with families' were used. All searches were limited to English language and the period from 2012-2020. We searched only for the articles that were available in full access. We used the program EndNote to arrange the literature and remove duplicates.

After the first search we identified 1232 papers which met our searching conditions. We excluded 71 duplicates. We have analyzed abstracts, titles, and key words of the remaining 1161 articles, and further exclude 1040 articles. Our exclusion criteria) were: (1) an article addresses only one of our search terms and does not place it in the broader context of familycentered care; (2) an abstract does not contain the word "family-centered" or its synonym; (3) an abstract does not link family-centered care with nursing (see also Table 2). After reading and comparing the remaining 121 articles, we additionally excluded 103 articles which we deemed to be irrelevant for our research, because they did not contain any definition of family-centered care or did not suggest at least one characteristic of family-centered care (exclusion criterion 4). We included 18 articles into the final thematical analysis. After conducting a thematical analysis we excluded additional three articles because they did not offer a comprehensive and clear definition of family-centered care (exclusion criterion 5). Thus, our thematical analysis was conducted on the basis of 15 articles. For a PRISMA diagram of our method, see Figure 1. For a list of the articles, together with their Index Factor (IF) see Table 1. For a list of the exclusion criteria see Table 2.

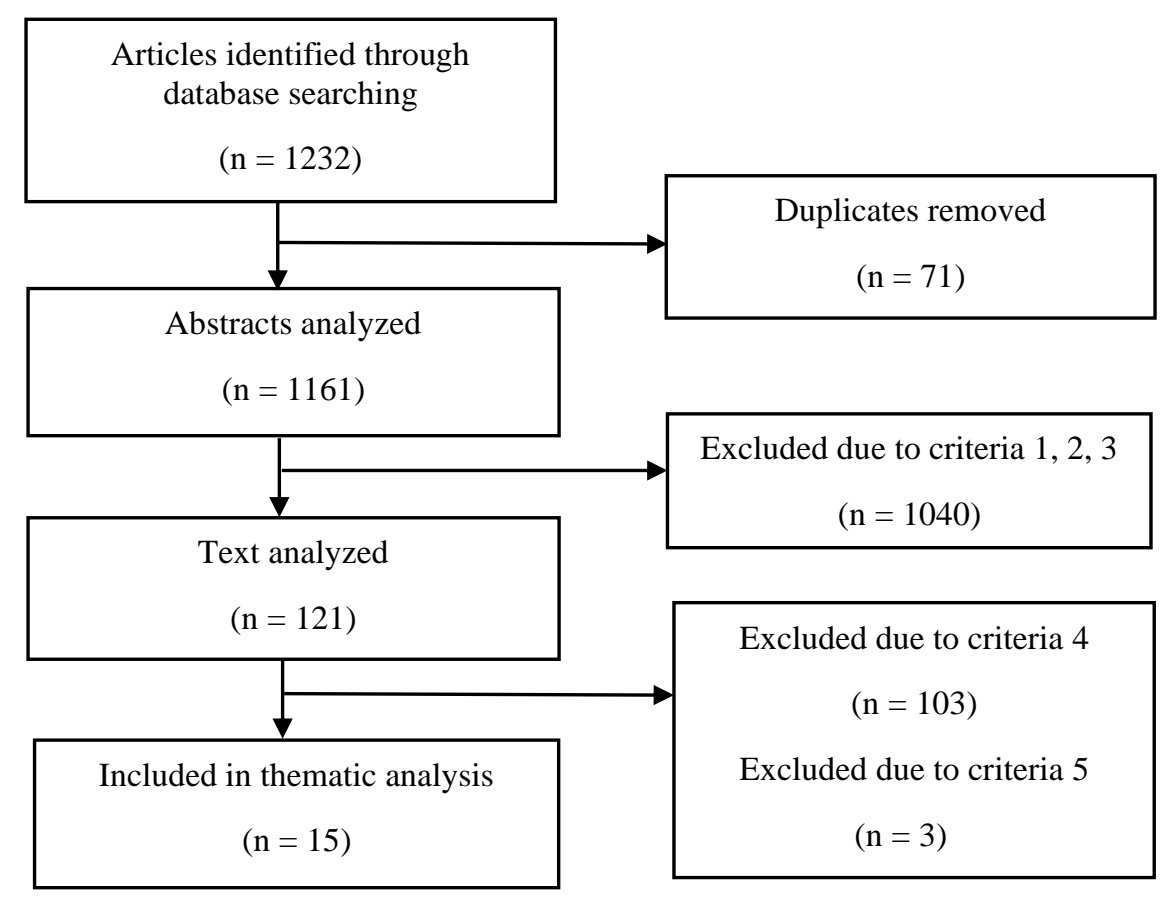

Figure 1 PRISMA diagram of our systematic review 
Table 1 The list of analyzed articles

\begin{tabular}{llc}
\hline & Author & IF of the journal \\
\hline 1) & Hertel et al., 2019 & 3.008 \\
2) & Petry, Ernst, Seinbrüchel-Boesch, Altherr, \& Naef, 2019 & 3.783 \\
3) & Deek et al., 2015 & 2.561 \\
4) & Foster et al, 2016 & $1.146^{*}$ (in 2017) \\
5) & Wolff et al., 2017 & 2.607 \\
6) & Mitchell, Chaboyer, Burmeister, \& Foster, 2009 & $2.105^{*}$ \\
7) & Luttik et al., 2016 & 2.296 \\
$8)$ & Davidson et al., 2017 & $7.414^{*}$ \\
9) & Benzein, Johansson, Årestedt, Berg, \& & 1.889 \\
& Saveman, 2008 & $1.987^{*}$ \\
10) & Kokorelias, Gignac, Naglie, \& Cameron, 2019 & $1.795^{*}$ \\
11) & Mackie, Mitchell, \& Marshall, 2019 & $2.562^{*}$ \\
$12)$ & Gusdal, Josefsson, Adolfsson, \& Martin, 2016 & $0.646^{*}$ \\
13) & Whiston, Barry, O’Keane, \& Darker, 2018 & $2.29^{*}$ \\
$14)$ & Hsu et al., 2019 & 3.783 \\
$15)$ & Park, Giap, Lee, Jeong, \& Go, 2018
\end{tabular}

Note: *The information about the IF was not included in SSCI. We have obtained it from Scimago Journal and Country Rank, avaliable on: https://www.scimagojr.com/

Table 2 The exclusion criteria

\begin{tabular}{cl}
\hline Number & \multicolumn{1}{c}{ Exlusion criterion } \\
\hline 1) & $\begin{array}{l}\text { The article addresses only one of our search terms and does not place it in the broader context of } \\
\text { family-centered care }\end{array}$ \\
\hline 2) & The abstract does not contain the word "family-centered" or its synonym \\
\hline 3$)$ & The abstract does not link family-centered care with nursing \\
\hline 4$)$ & $\begin{array}{l}\text { The article does not contain any definition of family-centered care or does not suggest at least one } \\
\text { characteristic of family-centered care at all }\end{array}$ \\
\hline 5$)$ & The article does not offer a comprehensive and clear definition of family-centered care \\
\hline
\end{tabular}

\section{Results}

In conducting a thematical analysis, our main aim was to individualize aspects which were most often addressed and stressed in the reviewed articles (see Table 3). These aspects are central for contemporary family-centered care. We have identified five key aspects of family centered care: communication; involvement of patients and family members; support to family members; organizational aspects and suggestions; attitude of nurses (see Figure 2). 


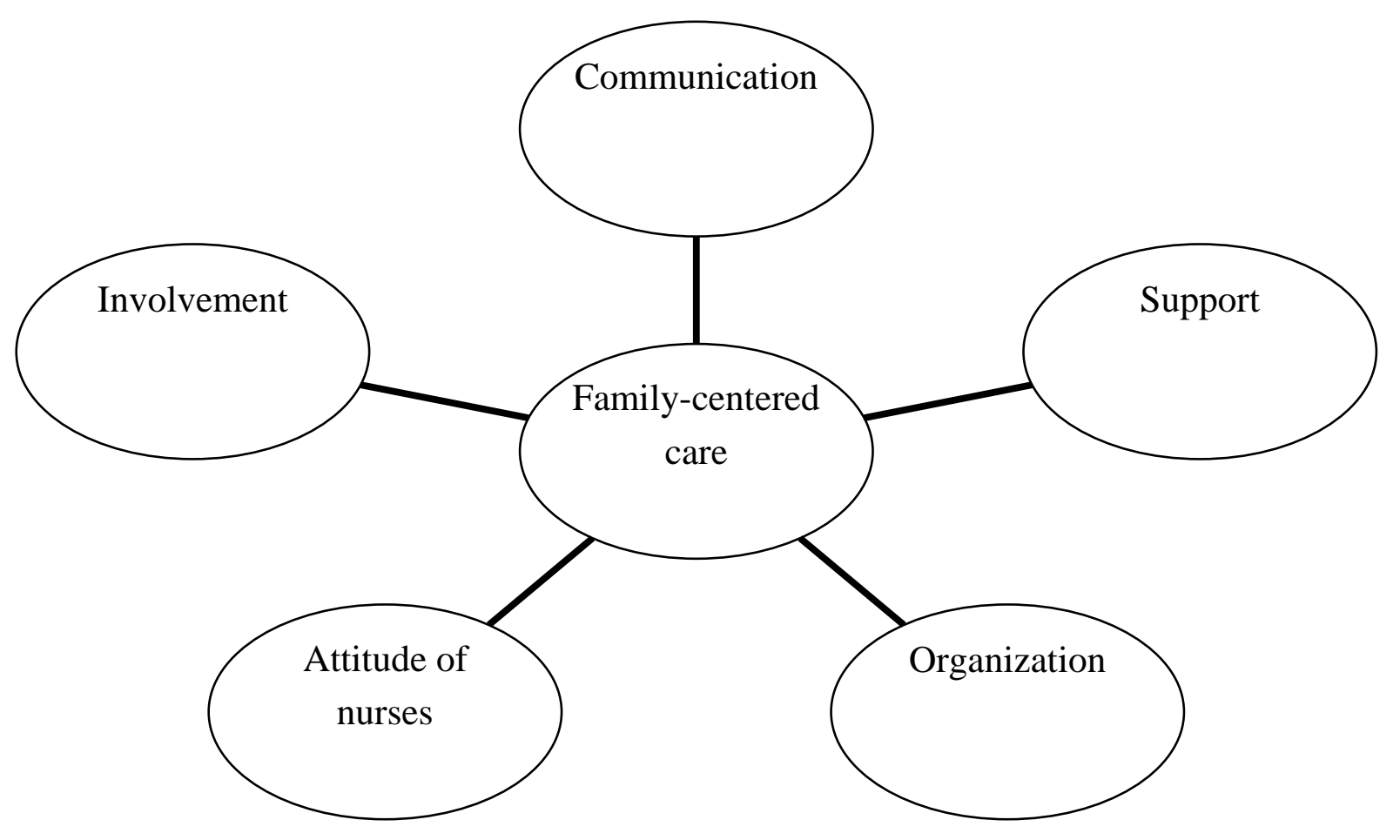

Figure 2. Family-centered care and its aspects 
Table 3. The list of key findings of the analyzed articles

\begin{tabular}{|c|c|c|}
\hline & Author & Key findings \\
\hline 1) & Hertel et al., 2019 & $\begin{array}{l}\text { Including patients as equal partners in healthcare is beneficent for all parties. } \\
\text { Organization design can improve participation of patients. }\end{array}$ \\
\hline 2) & $\begin{array}{l}\text { Petry, Ernst, } \\
\text { Seinbrüchel-Boesch, } \\
\text { Altherr, \& Naef, } \\
2019\end{array}$ & $\begin{array}{l}\text { Seven core dimensions were identified. In relation to care for persons with } \\
\text { cognitive impairment, caring attentiveness and responsiveness were important; } \\
\text { family members valued access to staff and information, participation in care, } \\
\text { and support over time. On a system level, available resources and the hospital } \\
\text { infrastructure were integral to their experience of hospitalization. }\end{array}$ \\
\hline 3) & Deek et al., 2015 & $\begin{array}{l}\text { Involving the family in self-care has shown positive results for patients with } \\
\text { chronic conditions. }\end{array}$ \\
\hline 4) & Foster et al, 2016 & $\begin{array}{l}\text { Six core and inter-related family-focused practices: family care planning and } \\
\text { goal-setting; liaison between families and services; instrumental, emotional and } \\
\text { social support; assessment; psychoeducation; and a coordinated system of } \\
\text { care between families and services. }\end{array}$ \\
\hline 5) & Wolff et al., 2017 & $\begin{array}{l}\text { Patients who delegated decision making are less active and think low of their } \\
\text { abilities. } \\
\text { Companions facilitate communication with health staff. } \\
\text { Ambiguity in companion's understanding of patient's needs can have negative } \\
\text { impact. }\end{array}$ \\
\hline 6) & $\begin{array}{l}\text { Mitchell, Chaboyer, } \\
\text { Burmeister, \& } \\
\text { Foster, } 2009\end{array}$ & $\begin{array}{l}\text { Partnering with patients' family members to provide fundamental care to the } \\
\text { patients significantly improves the respect, collaboration, support, and overall } \\
\text { scores on the family-centered care survey at } 48 \text { hours. }\end{array}$ \\
\hline 7) & Luttik et al., 2016 & $\begin{array}{l}\text { In general, nurses viewed the family as important in care. } \\
\text { Attitudes towards actively inviting families to take part in patient care were less } \\
\text { positive. } \\
\text { Higher educational level of nurses is associated with more positive attitudes } \\
\text { toward family involvement in healthcare. }\end{array}$ \\
\hline 8) & $\begin{array}{l}\text { Davidson et al., } \\
2017\end{array}$ & $\begin{array}{l}\text { Guidelines for family-centered care regarding: communication with family } \\
\text { members, family presence, family support, consultations and intensive care unit } \\
\text { team members, and operational and environmental issues. }\end{array}$ \\
\hline 9) & $\begin{array}{l}\text { Benzein, Johansson, } \\
\text { Årestedt, Berg, \& } \\
\text { Saveman, } 2008\end{array}$ & $\begin{array}{l}\text { Article describes the development and testing of a research instrument, } \\
\text { Families' Importance in Nursing Care-Nurses' Attitudes (FINC-NA), } \\
\text { designed to measure nurses' attitudes about the importance of involving } \\
\text { families in nursing care. }\end{array}$ \\
\hline 10) & $\begin{array}{l}\text { Kokorelias, Gignac, } \\
\text { Naglie, \& Cameron, } \\
2019\end{array}$ & $\begin{array}{l}\text { Key components to facilitate family-centered care are: collaboration between } \\
\text { family members and health care providers; consideration of family contexts; } \\
\text { policies and procedures; patient, family, and health care professional education. }\end{array}$ \\
\hline 11) & $\begin{array}{l}\text { Mackie, Mitchell, \& } \\
\text { Marshall, } 2019\end{array}$ & $\begin{array}{l}\text { Most patients and families perceived staff communication as disconnected and } \\
\text { inadequate, which constrained them from engaging in care processes or } \\
\text { decision-making. } \\
\text { When family felt empowered and participated in patient care, the quality of } \\
\text { health care was enhanced. }\end{array}$ \\
\hline 12) & $\begin{array}{l}\text { Gusdal, Josefsson, } \\
\text { Adolfsson, \& } \\
\text { Martin, } 2016\end{array}$ & $\begin{array}{l}\text { Registered nurses were supportive of families' involvement. } \\
\text { Attitudes toward inviting families to actively take part in heart failure nursing } \\
\text { care were less supportive. } \\
\text { Factors predicting the most supportive attitudes were to have a postgraduate } \\
\text { specialization, education in cardiac and/or heart failure nursing care, and a } \\
\text { competence to work with families. }\end{array}$ \\
\hline 13) & $\begin{array}{l}\text { Whiston, Barry, } \\
\text { O'Keane, \& Darker, } \\
2018\end{array}$ & Patients and family members need to be updated in how their opinions are used. \\
\hline 14) & Hsu et al., 2019 & $\begin{array}{l}\text { Identification of key components of diginity and respect in family-centered care: } \\
\text { building relationship; providing individualized care; respecting patients' } \\
\text { time. }\end{array}$ \\
\hline 15) & $\begin{array}{l}\text { Park, Giap, Lee, } \\
\text { Jeong, \& Go, } 2018\end{array}$ & $\begin{array}{l}\text { The literature review showed that patient- and family-centered care could be a } \\
\text { critical approach for improving the quality of health care. }\end{array}$ \\
\hline
\end{tabular}




\subsection{Communication}

Communication is one of the defining characteristics of any intersubjective reality. Several of the articles that we analyzed in our review emphasized the importance of proper and correct sharing of information in family-centered care. This was done either by stressing positive aspects of proper communication (Davidson et al., 2017, 106; Kokorelias, Gignac, Naglie, \& Cameron, 2019, p. 6; Mackie, Michell, \& Marshall, 2019, p. 7; Park, Giap, Lee, Jeong, \& Go, 2019, p. 81; Petry, Ernst, Seinbrüchel-Boesch, Altherr, \& Naef, 2019, p. 44) or by pointing to the negative consequences of poor, disconnected communication (Mackie, Michell, \& Marshall, 2019, p. 2). One of the factors of disconnected communication is poor health literacy of patients and family members, which often significantly decreases their involvement and participation in care (Mackie, Michell, \& Marshall, 2019, p. 2). Thus, some authors stress the importance of education about care provision and disease (Kokorelias, Gignac, Naglie, \& Cameron, 2019, p. 6) as well as the importance of education in relation to post-hospitalization phase (Petry, Ernst, Seinbrüchel-Boesch, Altherr, \& Naef, 2019, p. 44). Sharing of the information should be conducted in a way that improves the understanding of patients and their family members (Mackie, Michell, \& Marshall, 2019, p. 7). On the other hand, health care providers are often neglectful of poor health literacy of patients and family members (Mackie, Michell, \& Marshall, 2019, p. 1). Some authors stressed the importance of education and training of health care providers (Davidson et al., 2017, p. 106; Park, Giap, Lee, Jeong, \& Go, 2019, p. 81) which facilities communication, prepares health care providers for work with patients and family members with different levels of health literacy, and enables health care providers to determine needs and shortcoming of patients and their families (Foster et al., 2016, pp. 19-20). Of all the health care providers Nurses spend the most time engaged in direct patient care and it is therefore essential they communicate effectively (Mackie, Michell, \& Marshall, 2019, p. 7). Communication between two parties is always two-sided and for this reason it is crucial that health care providers have an insight into the state of patients through unique and special expertise that only patients and their family members can provide (Mackie, Michell, \& Marshall, 2019, p. 8).

\subsection{Involvement of patients and family members}

One of the defining characteristics of family-centered care is the active role of patient and family members in the process of health care. The articles that were taken into our review used two terms to address activity of patients and family members in health care processes: involvement (Deek et al., 2015, p. 976; Hertel et al., 2019, p. 44; Mitchell, Chaboyer, Burmeister, \& Foster, 2009, p. 551); and participation (Davidson et al., 2017, p. 106; Park, Giap, Lee, Jeong, \& Go, 2019, p. 81; Petry, Ernst, Seinbrüchel-Boesch, Altherr, \& Naef, 2019, p. 44; Whiston, Barry, O’Keane, \& Darker, 2018, p. 9). These two terms are interconnected and were used interchangeably. Whiston, Barry, O'Keane, and Darker (2018, p. 8) define patient and family participation as follows: "Patient and family participation is when the views and experiences of patients and families are sought and taken into account in healthcare." The idea of patient involvement follows from the premise that patients should be 
provided with holistic care (Mitchell, Chaboyer, Burmeister, \& Foster, 2009, p. 551) and is thus intrinsically linked to the concept of family-centered care which stresses the importance of the intersubjective unit of care that consists of a patient, family members, and health care providers. Patients and family members can be involved in the process of health care on various levels. They can participate in main activities of care, they can be involved in the sharing of information, and they can participate in joint-decision making (Park, Giap, Lee, Jeong, \& Go, 2019, p. 81). The importance of participation in healthcare has been established globally (Whiston, Barry, O’Keane, \& Darker, 2018, p. 9). It leads to a greater satisfaction of patients, family members, and health care providers (Hertel et al., 2019, p. 44), it shows improved outcomes in health care processes (Deek et al., 2015, p. 976), and it helps patients and family members to maintain control over patients' care plan and delivering (Kokorelias, Gignac, Naglie, \& Cameron, 2019, pp. 5-6). An important aspect of involvement of family members in health care processes is also the positive effect they can have on the patient (Mackie, Michell, \& Marshal, 2019, pp. 6-7). However, health care providers sometimes express their scruples toward involving family members in health care process (Luttik et al., 2016, 9). Mitchell, Chaboyer, Burmeister, \& Foster (2009, p. 544) suggest that such scruples could originate in the complexity of their work, while other authors pointed out that low experience and education could be the cause for the scruples (Luttik et al., 2016, p. 7).

\subsection{Support to family members}

Another aspect of family-centered care that was often stressed by the authors is support provided to family members and patients (Petry, Ernst, Seinbrüchel-Boesch, Altherr, \& Naef, 2019, pp. 44; Park, Giap, Lee, Jeong, \& Go, 2018, pp. 81; (Kokorelias, Gignac, Naglie, \& Cameron, 2019, 6). Family members and patients can receive different kind of support such as instrumental (practical), emotional, and social (broadening social skills) support (Foster et al., 2016, p. 16). Physical support is an important part of family-centered care (Park, Giap, Lee, Jeong, \& Go, 2018, p. 81). Family members can experience negative impact on their own well-being and in such situation, it is crucial that models of family-centered care are supportive of them (Kokorelias, Gignac, Naglie, \& Cameron, 2019, p. 6). In general, supporting family members increases their satisfaction and this is intrinsically connected with including family members in health care processes (Petry, Ernst, Seinbrüchel-Boesch, Altherr, \& Naef, 2019, p. 50). However, some authors identified possible negative impacts of the family members' support, especially due to ambiguity in their understanding of patient perspectives (Wolff et al., 2017, p. 492).

\subsection{Organizational aspects and suggestions}

Any system of interconnected factors is itself more than just a sum of its parts. The concept of family-centered care builds upon this supposition. Thus, several authors stressed the importance of organizational solutions in the sphere of family-centered care. In practice this means that special policies implemented that would promote family-centered care should be implemented (Davidson et al., 2017, p. 118). Usually authors suggested that the institution 
which provides health care should also establish policies that would incorporate needs and demands of their employees, patients, and family members (Davidson et al., 2017, p. 106; Kokorelias, Gignac, Naglie, \& Cameron, 2019, p. 7). Authors proposed policies that would build communication skills of health care providers (Davidson et al. 2017, p. 106). Another important aspect of proposed policies was encouraging family and patient participation in health care (Foster et al., 2016, pp. 21-22). Such policies should cover different aspects of family-centered care such as family presence, family support, communication, and operational and environmental issues (Davidson et al., 2017, p. 106-107).

\subsection{Attitudes of nurses}

One of the dynamics which was pointed out by the authors is the relationship between readiness or capability of healthcare providers to involve patients and family members and between the quality of health care (Luttik et al. 2016, p. 2). The quality of the encounter is likely to be influenced by the attitude nurses hold towards family role. To hold positive and supportive attitudes is essential for inviting and involving families in nursing care, while negative attitudes lead nurses to minimalize family involvement (Gusdal, Josefsson, Adolfsson, \& Martin 2016, pp. 256-257). Benzin et al. (2008) provided an instrument which measures nurses' attitudes about the importance of families in nursing care. This instrument was further used by Luttik et al. (2016) and Gusdal, Josefsson, Adolfsson, \& Martin (2017). Nurses are of special importance in providing health care because they spend the most time with patients and family members (Mackie, Mitchell, \& Marshall, 2019, p. 7)

Comparing these two studies, one can see that they both reached similar conclusions. Generally, nurses are supportive of families' involvement (Gusdal, Josefsson, Adolfsson, \& Martin, 2017, p. 256) and agree that presence of family members is important (Luttik et al., 2016, p. 3). However, both studies reported that attitudes toward inviting family to actively took part in patient's care were less positive (Gusdal, Josefsson, Adolfsson, \& Martin, 2017, p. 256; Luttik et al., 2016, p. 9). The difference appeared between opinion of older, more experienced nurses and younger nurses with less education. More experienced and more educated nurses had more positive opinion about family involvement (Gusdal, Josefsson, Adolfsson, \& Martin, 2017, p. 256; Luttik et al., 2016, p. 9). While trying to identify the reasons for this trend, both studies stressed the fact that younger nurses are more focused on individual patient and more occupied with their own learning (Gusdal, Josefsson, Adolfsson, \& Martin, 2017, p. 256; Luttik et al., 2016, p. 262). The presence of family makes them feel that they are checked-up and cause them additional stress (Luttik et al., 2016, p. 4).

Both studies stressed the importance of education on the importance of families and active family involvement in patient care (Luttik et al., 2016, p. 9; Gusdal, Josefsson, Adolfsson, \& Martin, 2017, p. 262) and thus both argued for a solution on organizational level. Gusdal, Josefsson, Adolfsson, \& Martin (2014, p. 262) Suggested that older, more experienced nurses could be encouraged to guide and mentor their younger and less experienced colleagues to strengthen their supportive attitudes toward families. 


\section{Discussion}

We identified five main characteristics of family-centered care that were stressed by the articles that were taken into account in our review. These are the importance of communication, involvement of family and family members, support to family members, organizational aspects and suggestions, and attitudes of nurses towards involvement of family members. From the abovementioned results and suggestions, we can draw some conclusions. The first is the importance of relations between patients, family members, and health care providers for effective and successful health care. This is something which can be already concluded from our definition of family-centered care as an intersubjective reality. Intersubjectiveness of family-centered care is clearly visible especially in the importance of relations between involved parties, which make the whole system more than just a sum of its parts. On many places it was stressed that satisfaction of all involved parties somehow depends on appropriate relations. This is the reason why many authors stressed the importance of proper communication that allows patient, family members, and heath care providers to properly express their needs, opinions, and demands.

Involvement of patients and family members on various levels of health process was also an important aspect that frequently appeared in the reviewed articles. As such, it is based in one of the basic convictions of family-centered care, i.e., that patient and family members form a unit of care and that is therefore crucial that they are somehow involved in the process of healthcare. Family involvement is also based upon the fact that family-centered care acknowledges special expertise of patients and their families which can contribute to the success of the health care process. Thus, involvement of family members improves the outcome of healthcare and at the same time also increases satisfaction of patients, healthcare providers, and family members.

On proper communication and relations depends also support which is needed by family members. Crucial in delivering support to family members is ability of health care providers to correctly assess health literacy and other abilities of family members and patient.

Almost all analyzed articles expressed the need for organizational solutions for the challenges that had been encountered. Such approach is again based on the premise that by establishing proper relations challenges can be efficiently addressed and solved. Organizational solutions exceed the limits of each included party, and arrange such parties in a way that optimizes satisfaction of all included parties. Organizational solutions are crucial for family-centered care because they take into account all included parties. Frequent mentioning of the need for policies that would arrange different aspects of family-centered care is an example of need for organizational solutions. Organizational solutions are as such able to take into consideration satisfaction of all parties and do not concentrate only on one of the parties.

On the side of healthcare providers there are especially nurses who are in constant touch with patients and family members. For family-centered care it is crucial that nurses are able to establish proper relations with patients and family members, because only in this way patients 
and family members can attain a greater level of satisfaction. The instrument developed by Benzein, Johansson, Årestedt, Berg, \& Saveman (2008) is very important in this domain, because it measures attitudes of nurses toward family involvement and identifies factors which influence nurses' attitudes. When nurses hold negative attitude toward involvement of family members in process of health care, the outcomes of healthcare are less effective. We can understand this fact from intersubjective character of every health care process. When proper relations are somehow damaged and are not fostered, this diminishes the level of final effectiveness and of satisfaction of all parties. Thus, it is important to understand what are the reasons for negative attitudes toward involving family members in healthcare process, because only in this way we can address them and try to surpass them with a solution on a systematical level which takes into consideration all included parties.

\section{Conclusion}

Family-centered care is a model of healthcare that takes into consideration all the parties included in health care process and tries to optimize the outcomes. Its basic conviction is that patients, healthcare providers and family members are all factors in a system and that therefore their satisfaction is interconnected. For optimization of satisfaction of all parties, family-centered care offers a systematic solution that takes into account all the parties involved. Crucial for such solution is proper and correct communication which is a basic dynamic of any intersubjective reality. Communication depends on many factors that should be addressed by correct policies. An important factor in family-centered care are the attitudes of nurses toward involvement of family members in health care processes. This problem was addressed by some authors who understood attitudes of nurses not only as their own conviction, but also as a factor that influences the effectiveness of health care. For this purpose, Benzein, Johansson, Årestedt, Berg, \& Saveman (2008) developed a special instrument that measures and determines factors that influence nurses' attitudes toward family involvement. Results that this instrument gives should be taken into account while preparing plans of family-centered care.

Our scoping-review of the literature on family-centered care contributes to the scientific field of health management by identifying the core characteristics of contemporary family-centered care theories and individualizing the main challenges. In this regard, our scoping-review could serve to managers and the responsible for organizing healthcare processes, because it presents demands and needs of both healthcare providers and consumers.

This scoping review is not without its limitations. Only articles published in English were included. We gave priority to the articles that were published during past few years. We did not include articles that did not go through peer review. We did not differentiate between different types of clinical environments, such as pediatric care, intensive care, etc. We concentrated only on articles that were available through the above-mentioned databases.

Further researches could be conducted on the basis of the results of the present study. One of the possibilities would be to carry out a quantitative study of measuring the 
interconnectedness of nurses' attitude toward family involvement in healthcare process. Other characteristics of family-centered care could be as well a subject of a possible quantitative research.

The authors received no financial support for the research, authorship, or publication of this article.

\section{References}

1. Benzein, E., Johansson, P., Årestedt, P. J., Berg, A., \& Saveman, B. I. (2008). Families' Importance in nursing Care: Nurses' Attitudes-An Instrument Development. Journal of Family Nursing, 14(1), 97117.

2. Bowlby, J. (1944a). Forty-four juvenile thieves: Theircharacters and home life (i). International Journal of Psychoanalysis, 25, 19-53.

3. Bowlby, J. (1944b). Forty-four juvenile thieves: Their characters and home life (ii). International Journal of Psychoanalysis, 25, 107-127.

4. Davidson, J. E., Alakson, R. A., Long, A. C., Puntillo, K. A., Kross, E. K., Hart, J., Cox, C. E., ... Curtis, J. R. (2017). Guidelines for Family-Centered Care in the Neonatal, Pediatric, and Adult ICU. Critical Care Medicine, 45(1), 103-128. doi: 10.1097/CCM.0000000000002169

5. Deek, H., Hamilton, S., Brown, N., Inglis, S. C., Digiacomo, M., Newton, P. J., Noureddine, S., MacDonald, P. S., \& Davidson, P. M. (2015). Family-centred approaches to healthcare interventions in chronic diseases in adults: a quantitative systematic review. Journal of Advanced Nursing, 72(5), 968-979. doi: 10.1111/jan.12885

6. Foster, K., Maybery, D., Reupert, A., Gladstone, B., Grant, A., Ruud, T., Falkov, A., \& Kowalenko, N. (2016). Family-focused practice in mental health care: An integrative review. Child \& Youth Services, 37(2), 129-155. doi: 10.1080/0145935X.2016.1104048

7. Gusdal, A. K., Josefsson, K., Adolfsson, E. T., \& Martin, L. (2017). Nurses' attitudes toward family importance in hearth failure care. European Journal od Cardiovascular Nursing, 16(3), 256-266. doi: $10.1177 / 1474515116687178$

8. Hertel, E., Cheadle, A., Matthys, J., Coleman, K., Gray, M., Robbins, M., Tufte, J., \& Hsu, C. (2019). Engaging patients in primary care design: An evaluation of a novel approach to codesigning care. Health Expectations, 22, 609-616. doi: 10.1111/hex.12909

9. Hsu, C., Gray, M. F., Murray, L., Abraham, M., Nickel, W., Sweeney, J. M., Frosch, D. L., Mroz, T. M., Ehrlich, K., Johnson, B., \& Reid, R. J. (2019). Actions and processes that patients, family members, and physicians associate with patient- and family-centered care. BMC Family Practice, (20) 35, 1-12. doi: 10.1186/s12875-019-0918-7

10. Johnson, B. H. (2000). Family-centered care: Four decades of progress. Families, Systems, \& Health, 18(2), 137-156. doi: 10.1037/h0091843

11. Jolley, J., \& Shields, L. (2009). The Evolution of Family-Centered Care. Journal of Pediatric Nursing, 24(2), 164-170. doi: 10.1016/j.pedn.2008.03.010

12. Kokorelias, K. M., Gignac, M. A. M., Naglie, G. \& Cameron, J. I. (2019). Towards a universal model of family centered care: a scoping review. BMC Health Services Research, 19(564), 1-12. doi: 10.1186/s12913-019-4394-5 
13. Kovacs, P. J., Bellin, M. H., \& Fauri, D. P. (2008). Family-Centered Care. Journal of Social Work in End-Of-Life \& Palliative Care, 2(1), 13-27. doi: 10.1300/J457v02n01_03

14. Luttik, MLA, Goossens, E., Ågren, S., Jaarsma, T., Mårtensson, J., Thompson, DR., Moons, P., \& Strömberg, A. (2016). Attitudes of nurses towards family involvement in the care for patients with cardiovascular diseases. European Journal of Cardiovascular Nursing, 16(4), 299-308. doi: $10.1177 / 1474515116663143$

15. Mackie, B. R., Mitchell, M., \& Marshall, A.P. (2019). Patient and family members' perceptions of family participation in care on acute care wards. Scandinavian Journal of Caring Sciences, 33(9), 359-370. doi: 10.1111/jan.13442

16. Mitchell, M., Chaboyer, W., Burmeister, E., \& Foster, M. (2009). Nursing Intervention on FamilyCentered Care in Adult Critical Care. American Journal of Critical Care, 18(6), 543-551. doi: 10.4037/ajcc2009226

17. Park, M., Giap, T. T. T., Lee, M., Jeong, H., \& Go, Y. (2018). Patient- and family-centered care interventions for improving the quality of health care: A review of systematic reviews. International Journal of Nursing Studies, 87, 69-83. doi: 10.1016/j.ijnurstu.2018.07.006

18. Petry, H., Ernst, J., Seinbrüchel-Boesch, C., Altherr, J., \& Naef, R. (2019). The acute care experience of older persons with cognitive imairnment and their families: A qualitative study. International Journal of Nursing Studies, 69, 44-52. doi: 10.1016/j.ijnurstu.2018.11.008

19. Robertson, J. (1970). Young children in hospital. London: Tavistock Publications.

20. Robertson, J., \& Bowlby, J. (1952). Responses of young children to separation from their mothers. Courrier Centre International de l'enfance, 2, 131-142.

21. Whiston, L., Barry, J., O'Keane, V., \& Darker, C. (2018). Patient, family and clinician preferences for the intensity and implementation of patient and family participation in healthcare design and delivery in psychiatry. The European journal of Psychiatry, 33(1), 8-16. doi: 10.1016/j.ejpsy.2018.07.001

22. Wolff, J.1., Guan, Y., Boyd, C. M., Vick, J., Amjad, H., Roth, D. L., Gitlin, L. N., \& Roter, D. L. (2017). Examing the context and helpfulness of family companion contributions to older adults' primary care visits. Patient Education and Counseling, 100(3), 487-494. doi:

10.1016/j.pec.2016.10.022

\begin{abstract}
$* * *$
Andreja Krajnc holds a Master's degree in social management from the Faculty of Organization Sciences (FOV) at the University of Maribor. As a sole proprietor with an obtained concession, she is actively involved in community nursing care of individuals, families, and communities. In the pedagogical sphere, she is teaching at Bachelor's degree level as a habilitated lecturer in the field of health care. She actively participates at various conferences and symposiums dedicated to nursing and health care, and publishes articles in various Slovenian journals. She is a doctoral student at the Faculty of Organization Studies in Novo Mesto.

$* * *$

Mateja Berčan, $\mathrm{PhD}$ is a specialist in gerontological nursing care. She is employed as a private community nurse. She is also a Lecturer in study program Social Gerontology and study program Physiotherapy at the Alma Mater Europaea-European Centre Maribor. Her career path is focused on researching the palliative care, gerontology and nursing care. Since 2012, she has been the authorized supervisor of the Health Insurance Institute of Slovenia for the implementation of financial and medical supervision in the field of community nursing care and nursing care in social welfare institutions.
\end{abstract}




\section{Povzetek:}

\section{Na družino osredotočena oskrba: pregled literature}

Raziskovalno vprašanje (RV): Kako sodobna znanstvena literatura pojmuje na družino osredotočeno oskrbo?

Namen: Predložiti celosten pregled literature, ki obravnava na družino osredotočeno oskrbo.

Metoda: Literaturo smo iskali v bazah podatkov, pri tem pa uporabili sledeča iskalna gesla: »na družino usmerjena oskrba, « »osredotočenost na družino, « »družinska nega« in »sodelovanje $\mathrm{z}$ družino.« Postopoma smo izločili članke, ki niso izpolnjevali naših pogojev. Članki, ki so te pogoje izpolnjevali, so bili kasneje tematsko analizirani.

Rezultati: Identificirali smo pet bistvenih značilnosti na družino osredotočene oskrbe: pomembnost komunikacije, vključenost pacientov in družinskih članov, podpora družinskim članom, organizacijski aspekti, ter odnos medicinskih sester. Poudarili smo, da na družino osredotočena oskrba predlaga sistemsko rešitev, ki teži k optimizaciji zadovoljstva vseh vpletenih, saj zdravstveno negovalni proces razume kot intersubjektivno realnost v kateri vključeni akterji vplivajo druga na drugo.

Organizacija: Rezultati bi lahko bili uporabljeni in upoštevani pri načrtovanju programa zdravstvene nege in oskrbe.

Družba: Rezultati te študije predlagajo sistemsko rešitev zdravstvene oskrbe, ki bi izboljšala dobrobit vseh vpletenih.

Originalnost: Raziskava vsebuje tematsko analizo literature ter obenem na izviren način sintetizira glavne namene na družino osredotočene oskrbe.

Omejitve/nadaljnje raziskovanje: V pregled smo vključili le članke, ki so bili objavljeni v angleškem jeziku. Pri raziskavi nismo ločevali med različnimi okolji v katerih se nudi zdravstvena nega.

Ključne besede: na družino usmerjena oskrbe, osredotočenost na družino, sodelovanje $\mathrm{z}$ družinami, družinska oskrba, zdravstvena nega, pregled literature, komunikacija, sistemske rešitve. 